\title{
Rosmarinic Acid, a Bioactive Phenolic Compound, Inhibits Glutamate Release from Rat Cerebrocortical Synaptosomes through $\mathrm{GABA}_{\mathrm{A}}$ Receptor Activation
}

\author{
Che-Chuan Wang ${ }^{1,2}$, Pei-Wen Hsieh ${ }^{3,4,5}{ }^{\mathbb{D}}$, Jinn-Rung Kuo ${ }^{1,2}$ and Su-Jane Wang ${ }^{3,6, *(\mathbb{D})}$ \\ 1 Chi Mei Medical Center, Department of Neurosurgery, Tainan 71004, Taiwan; \\ wangchechuan@gmail.com (C.-C.W.); koujinnrung@gmail.com (J.-R.K.) \\ 2 Biotechnology, Southern Taiwan University of Science and Technology, Tainan 71005, Taiwan \\ 3 Research Center for Chinese Herbal Medicine, College of Human Ecology, Chang Gung University of Science \\ and Technology, Taoyuan 33303, Taiwan; pewehs@mail.cgu.edu.tw \\ 4 Graduate Institute of Natural Products, School of Traditional Chinese Medicine, and Graduate Institute of \\ Biomedical Sciences, College of Medicine, Chang Gung University, Taoyuan 33303, Taiwan \\ 5 Department of Anesthesiology, Chang Gung Memorial Hospital, Taoyuan 33303, Taiwan \\ 6 School of Medicine, Fu Jen Catholic University, New Taipei City 24205, Taiwan \\ * Correspondence: med0003@mail.fju.edu.tw; Tel.: +886-2-29053465
}

check for updates

Citation: Wang, C.-C.; Hsieh, P.-W.; Kuo, J.-R.; Wang, S.-J. Rosmarinic Acid, a Bioactive Phenolic

Compound, Inhibits Glutamate

Release from Rat Cerebrocortical Synaptosomes through GABA $_{\mathrm{A}}$ Receptor Activation. Biomolecules 2021, 11, 1029. https://doi.org/ 10.3390/biom11071029

Academic Editor: Chi-Feng Hung

Received: 3 July 2021

Accepted: 13 July 2021

Published: 15 July 2021

Publisher's Note: MDPI stays neutral with regard to jurisdictional claims in published maps and institutional affiliations.

Copyright: (C) 2021 by the authors Licensee MDPI, Basel, Switzerland. This article is an open access article distributed under the terms and conditions of the Creative Commons Attribution (CC BY) license (https:/ / creativecommons.org/licenses/by/ $4.0 /)$.

\begin{abstract}
Rosmarinic acid, a major component of rosemary, is a polyphenolic compound with potential neuroprotective effects. Asreducing the synaptic release of glutamate is crucial to achieving neuroprotectant's pharmacotherapeutic effects, the effect of rosmarinic acid on glutamate release was investigated in rat cerebrocortical nerve terminals (synaptosomes). Rosmarinic acid depressed the 4-aminopyridine (4-AP)-induced glutamate release in a concentration-dependent manner. The removal of extracellular calcium and the blockade of vesicular transporters prevented the inhibition of glutamate release by rosmarinic acid. Rosmarinic acid reduced 4-AP-induced intrasynaptosomal $\mathrm{Ca}^{2+}$ elevation. The inhibition of $\mathrm{N}$-, $\mathrm{P} / \mathrm{Q}$-type $\mathrm{Ca}^{2+}$ channels and the calcium/calmodulin-dependent kinase II (CaMKII) prevented rosmarinic acid from having effects on glutamate release. Rosmarinic acid also reduced the 4-AP-induced activation of CaMKII and the subsequent phosphorylation of synapsin I, the main presynaptic target of CaMKII. In addition, immunocytochemistry confirmed the presence of $\mathrm{GABA}_{\mathrm{A}}$ receptors. $\mathrm{GABA}_{\mathrm{A}}$ receptor agonist and antagonist blocked the inhibitory effect of rosmarinic acid on 4-AP-evoked glutamate release. Docking data also revealed that rosmarinic acid formed a hydrogen bond with the amino acid residues of $\mathrm{GABA}_{\mathrm{A}}$ receptor. These results suggested that rosmarinic acid activates $\mathrm{GABA}_{\mathrm{A}}$ receptors in cerebrocortical synaptosomes to decrease $\mathrm{Ca}^{2+}$ influx and CaMKII/synapsin I pathway to inhibit the evoked glutamate release.
\end{abstract}

Keywords: rosmarinic acid; glutamate release; $\mathrm{GABA}_{\mathrm{A}}$ receptor; voltage-gated $\mathrm{Ca}^{2+}$ channel; CaMKII; synapsin I; synaptosome

\section{Introduction}

Glutamate is the main excitatory neurotransmitter of the central nervous system (CNS) and acts through glutamate receptors to modulate synaptic transmission. Under physiological conditions, glutamatergic neurotransmission is required for normal neuronal function and is involved in learning and memory processes [1]. However, excessive glutamate release successively causes the overactivation of glutamate receptors, highlevels of $\mathrm{Ca}^{2+}$ entry into neurons, protease activation, mitochondrial damage, free radical generation, and finally neuronal death [2,3]. This process, known as excitotoxicity, is the mechanism underlying numerous CNS diseases [4,5]. Modulating synaptic glutamate release is thus a valuable strategy for reducing neurotoxicity and protecting the brain [6-8].

Plant-derived compounds have received considerable attention for their neuroprotective activities [9,10]. Rosemary (Rosmarinus officinalis L.), a common household plant, is a 
herb used in cooking, teas, and folk remedies [11]. In folk and traditional medicine, rosemary is used for the treatment of headache, dysmenorrhea, stomachache, insomnia, hysteria, epilepsy, and depression [12]. Its antiviral [13], antioxidant [14], anti-inflammatory [15], anti-tumorigenic [16], antinociceptive [17], antidepressant [18], neuroprotective [19], and memory-enhancing properties [20], among others, have been reported. We focused our bioactivity analysis on rosmarinic acid (Figure 1A), which has been indicated to possess neuroprotective effects in various models of ischemia and neurodegeneration [21,22], as well as in chemical-induced neurotoxicity and oxidative stress [23-25]. The neuroprotective properties of rosmarinic acid and the involvement of the glutamatergic system in excitotoxicity [2,4] prompted us to evaluate its potential role in the regulation of glutamate release. Therefore, this study used rat cerebrocortical nerve terminals (synaptosomes) to investigate the effect of rosmarinic acid on glutamate release and elucidate the relevant mechanisms.

A<smiles>O=C(/C=C/c1ccc(O)c(O)c1)OC(Cc1ccc(O)c(O)c1)C(=O)O</smiles>

$\mathrm{B}$

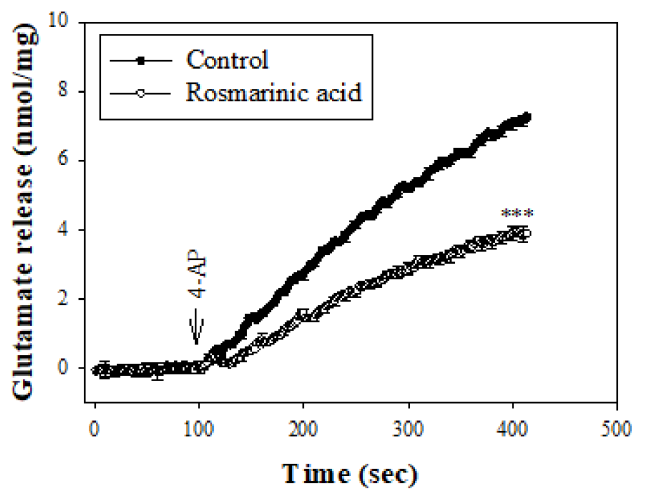

C

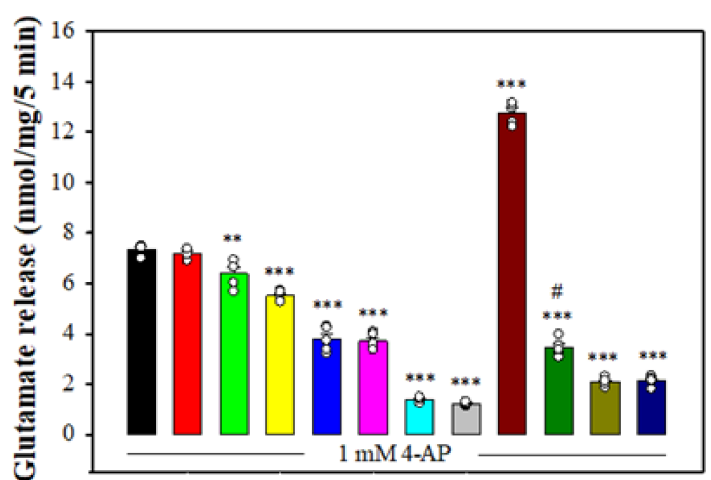

$\begin{array}{llllllllllllll}1.2 & 1.2 & 1.2 & 1.2 & 1.2 & 1.2 & - & - & 1.2 & 1.2 & 1.2 & 1.2 & \mathrm{CaCl}_{2}(\mathrm{mM})\end{array}$

$\begin{array}{llllllllllllll} & 1 & 5 & 10 & 30 & 50 & - & 30 & - & 30 & - & 30 & \text { Rosmarinic } \operatorname{acid}(\mu \mathrm{M})\end{array}$

- - - - - - $300300 \quad-\quad-\quad$ EGTA $(\mu \mathrm{M})$

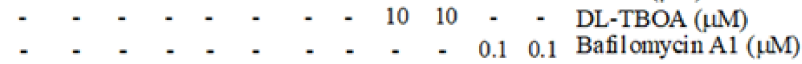

Figure 1. Effect of rosmarinic acid on 4-AP-evoked glutamate release from rat cerebrocortical nerve terminals. (A) The chemical structure of rosmarinic acid. (B) Glutamate release was measured under control conditions or in the presence of rosmarinic acid added $10 \mathrm{~min}$ prior to the addition of 4AP. (C) Effect of rosmarinic acid at different concentrations on 4-AP-evoked glutamate release and extracellular $\mathrm{Ca}^{2+}$-free solution, glutamate transporter inhibitor DL-TBOA or vesicular release inhibitor bafilomycin A1 on the effect of rosmarinic acid. Rosmarinic acid, DL-TBOA or bafilomycin A1 was added 10 min before depolarization. Data are mean $\pm \operatorname{SEM}\left(n=5\right.$ per group). ${ }^{* *} p<0.01,{ }^{* * *} p<0.001$ compared with the control group. ${ }^{\#} p<0.001$ compared with the DL-TBOA-treated group.

\section{Materials and Methods}

\subsection{Animals}

Male Sprague-Dawley rats (150-200 g, BioLASCO Inc., Taipei, Taiwan) were cared for in accordance with the guidelines of the Care and Use of Laboratory Animals (NAC 2011). 
All the procedures were approved by the Fu Jen Institutional Animal Care and Utilization Committee (IACUC No. A10812).

\subsection{Isolation of Synaptosomes from the Rat}

Synaptosomes were isolated as previously described [26]. Animals were sacrificed via cervical dislocation and the cerebral cortex were rapidly removed. The brain tissue was homogenized in $320 \mathrm{mM}$ sucrose solution and centrifuged at $3000 \times \mathrm{g}$ for $10 \mathrm{~min}$. The supernatant was stratified on Percoll discontinuous gradients and centrifuged at 32,500 $\times g$ for $7 \mathrm{~min}$. The synaptosomal fraction was collected and centrifuged for $10 \mathrm{~min}$ at $27,000 \times g$. Protein concentration was determined using the Bradford assay. Synaptosomes were centrifuged at $3000 \times \mathrm{g}$ for $10 \mathrm{~min}$ in the final wash to obtain synaptosomal pellets with $0.5 \mathrm{mg}$ protein.

\subsection{Measurement of Glutamate Release}

For the glutamate release experiments, the synaptosomal pellet ( $0.5 \mathrm{mg}$ protein) was resuspended in the Hepes-buffered solution and glutamate release was assayed by on-line fluorimetry [27]. $\mathrm{CaCl}_{2}(1.2 \mathrm{mM})$, glutamate dehydrogenase $(\mathrm{GDH}, 50$ units $/ \mathrm{mL})$ and $\mathrm{NADP}^{+}(2 \mathrm{mM})$ were added at the start of incubation. Glutamate release was induced with 4-AP $(1 \mathrm{mM})$ and monitored by measuring the increase of fluorescence (excitation and emission wavelengths of 340 and $460 \mathrm{~nm}$, respectively) resulting from NADPH being produced by the oxidative deamination of released glutamate by GDH. Released glutamate was calibrated by a standard of exogenous glutamate $(5 \mathrm{nmol})$ and expressed as nanomoles glutamate per milligram synaptosomal protein $(\mathrm{nmol} / \mathrm{mg})$.

\subsection{Measurement of Intrasynaptosomal $\mathrm{Ca}^{2+}$ Concentration $\left(\left[\mathrm{Ca}^{2+}\right]_{i}\right)$}

Synaptosomes ( $0.5 \mathrm{mg}$ protein) were incubated in the Hepes-buffered solution containing Fura 2-AM $(5 \mu \mathrm{M})$ and $\mathrm{CaCl}_{2}(0.1 \mathrm{mM})$ for $30 \mathrm{~min}$ at $37^{\circ} \mathrm{C}$. Samples were centrifuged for $1 \mathrm{~min}$ at $5000 \mathrm{rpm}$, and pellets were resuspended in Hepes-buffered medium containing $\mathrm{CaCl}_{2}(1.2 \mathrm{mM})$. Fura-2-Ca fluorescence was monitored at $5 \mathrm{~s}$ intervals for $5 \mathrm{~min}$. $\left[\mathrm{Ca}^{2+}\right]_{\mathrm{i}}(\mathrm{nM})$ was calculated by using calibration procedures and equations described previously [28].

\subsection{Measurement of Membrane Potential}

The synaptosomal membrane potential was assayed with a positively charged membrane potential-sensitive carbocyanine dye $\mathrm{DiSC}_{3}(5)$ [29]. $\mathrm{DiSC}_{3}(5)$ fluorescence was monitored at $2 \mathrm{~s}$ intervals and data are expressed in fluorescence units.

\subsection{Western Blot}

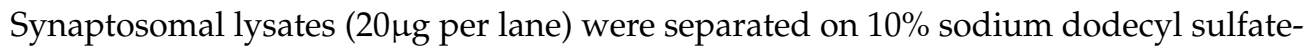
polyacrylamide gel electrophoresis (SDS-PAGE) and transferred onto nitrocellulose membranes, incubated with anti-CaMKII (1:10,000, Cell Signaling, Beverly, MA, USA), anti-pCMKII (1:2000, Cell Signaling, Beverly, MA, USA), anti-synapsin I (1:30,000, Cell Signaling, Beverly, MA, USA), and anti-p-synapsin I (Serine 603) (1:2000, GeneTex, Irvine, CA, USA) antibodies for overnight at $4{ }^{\circ} \mathrm{C}$. This was followed by washing with Tris-buffered saline containing $0.1 \%$ Tween 20 (TBST) and incubation with horseradish peroxidase-conjugated secondary antibodies (1:5000, Cell Signaling, Beverly, MA, USA) for $2 \mathrm{~h}$ at room temperature. Immunoreactive bands were visualized by chemiluminescence (GeneTex, Irvine, CA, USA). Quantification was obtained by scanning densitometry of five independent experiments, and analyzed with Image J software (version 1.43, Bethesda, MD, USA) [30].

\subsection{Immunocytochemistry}

The synaptosomes were attached to the polylysine-coated coverslips for $40 \mathrm{~min}$ at $4{ }^{\circ} \mathrm{C}$, fixed with $4 \%$ paraformaldehyde in $0.1 \mathrm{M}$ phosphate buffer (pH 7.4) for $30 \mathrm{~min}$, permeabilized with $0.2 \%$ Triton X-100 for $60 \mathrm{~min}$ and incubated for $24 \mathrm{~h}$ with a mixture primary 
antibodies against vesicular transporter of glutamate type 1 (VGLUT1, 1:200; Abcam, Cambridge, UK) and $\mathrm{GABA}_{\mathrm{A}}$ receptor $\alpha 1$ subunit(1:100; Abcam, Cambridge, UK) for 90 min at room temperature. After rinsing with blocking buffer, the synaptosomes were incubated with a mixture of goat anti-mouse DyLight 549-and goat anti-rabbit fluoresceinisothiocyanate (FITC)-conjugated secondary antibodies (1:200; Invitrogen, Carlsbad, CA, USA) for $1 \mathrm{~h}$ at room temperature. The synaptosomes were then washed three times with phosphate buffer and 0.1 M carbonate buffer ( $\mathrm{pH}$ 9.2), and the coverslips were mounted with fluoromount (DAKO North America, Inc., Carpinteria, CA, USA). Images were acquired in an Image Xpress micro confocal (Molecular Devices, San Jose, CA, USA).

\subsection{Molecular Docking Study}

The molecular docking experiment was performed using the tools of CDOCKER in Discovery Studio 4.1 client. The molecular structure of GABA $_{\mathrm{A}}$ receptor protein (PDB ID 4COF) from the RCSB Protein Data Bank was prepared with the standard protocol using Discovery Studio 4.1 client. The optimized structure of rosmarinic acid was created using flexibly docked following the default setting in software, and then inserted into the probable binding poses of the active site in protein.

\subsection{Statistical Analysis}

Reported data were expressed as means \pm standard error of the mean (SEM). To assess statistical differences between two groups, the unpaired (two-tailed) Student's $t$ test was used. Multiple comparisons were performed with the analysis of variance (ANOVA) followed by Tukey's post hoc test. Differences were considered as statistically significant at $p<0.05$.

\subsection{Chemicals}

Rosmarinic acid (purity $>98 \%$, ChemFace, Wuhan, China), bafilomycin A1 (Tocris Bioscience, Bristol, United Kingdom), dantrolene (Tocris Bioscience), 7-chloro-5-(2-chlorophenyl)1,5-dihydro-4,1-benzothiazepin-2(3H)-one (CGP37157, Tocris Bioscience), N-[2-(p-bromocinna mylamino)ethyl]-5-isoquinolinesulfonamide (H89, Tocris Bioscience), bisindolylmaleimide I (GF109203X, Tocris Bioscience), 1-[N,O-Bis(5-isoquinolinesulfonyl)-N-methyl-L-tyrosyl]-4phenylpiperazine (KN62, Tocris Bioscience), 3,3,3-dipropylthiadicarbocyanine iodide [DiSC3(5)] (Thermo, Waltham, MA, USA), and fura-2-acetoxymethyl ester (Fura-2-AM, Thermo) were made up in $10 \mathrm{mM}$ stock solution in DMSO. DL-threo- $\beta$-benzyloxyaspartate (DL-TBOA, Tocris Bioscienc), $\omega$-conotoxin GVIA ( $\omega$-CgTX GVIA, Alomone Lab, Jerusalem, Israel), and $\omega$-agatoxin IVA ( $\omega$-Aga IVA, Alomone Lab) were made up in $5 \mathrm{mM}$ stock solution in water. 4-aminopyridine (4-AP, Sigma-Aldrich, St. Louis, MO, USA) were made up in $300 \mathrm{mM}$ stock solution in water.

\section{Results}

\subsection{Effect of Rosmarinic Acid on the 4-AP-Evoked Glutamate Release in Rat Cerebrocortical Synaptosomes}

To investigate the effect of rosmarinic acid on glutamate release, synaptosomes isolated from rat cerebral cortex were stimulated by $1 \mathrm{mM} 4-\mathrm{AP}$, which opens voltage-gated $\mathrm{Ca}^{2+}$ channels (VGCCs) and induces the release of glutamate [31]. As shown in Figure 1B, preincubation with rosmarinic acid $(30 \mu \mathrm{M})$ for $10 \mathrm{~min}$ before 4 -AP addition did not produce any significant effect on the basal release of glutamate, but markedly reduced the 4-AP-induced release of glutamate release in the presence of $1.2 \mathrm{mM} \mathrm{CaCl}_{2}(n=5$, $p<0.001$ vs. control group). At concentrations of $1-50 \mu \mathrm{M}$, the effects of rosmarinic acid were concentration-dependent (Figure $1 \mathrm{C}$ ) with an $\mathrm{IC}_{50}$ of $11 \mu \mathrm{M}$ and maximum inhibition of $48.8 \pm 2.5 \%$. In addition, 4 -AP-evoked glutamate release was reduced in $\mathrm{Ca}^{2+}$-free media (plus EGTA) $(p<0.001)$. In $\mathrm{Ca}^{2+}$-free conditions (plus EGTA), rosmarinic acid failed to reduce the release of glutamate evoked by 4 -AP ( $n=5, p=0.9$; Figure $1 \mathrm{C}$ ). On the other hand, 4-AP-evoked glutamate release was increased in the presence of 
DL-TBOA, an inhibitor of the plasma membrane glutamate transporter, which blocks the $\mathrm{Ca}^{2+}$-independent nonvesicular efflux by transporter reversal $(n=5, p<0.001$ vs. control group). With DL-TBOA present, rosmarinic acid significantly inhibited the 4-APevoked glutamate release ( $n=5, p<0.001$ vs. the DL-TBOA-treated group, Figure $1 C)$. By contrast, bafilomycin A1, an inhibitor of vesicular glutamate transporters, reduced 4-APevoked glutamate release ( $p<0.001$ vs. control group). In the presence of bafilomycin A1, rosmarinic acid failed to produce significant inhibition ( $p=0.98 \mathrm{vs}$. bafilomycin A1-treated group, Figure 1C).

\subsection{Effect of Rosmarinic Acid on $\left[\mathrm{Ca}^{2+}\right]_{i}$ and Membrane Potential}

Table 1 shows that 4 -AP $(1 \mathrm{mM})$ elicited a rise in $\left[\mathrm{Ca}^{2+}\right]_{\mathrm{i}}$ and rosmarinic acid preincubation reduced the 4-AP-induced $\left[\mathrm{Ca}^{2+}\right]_{\mathrm{i}}$ increase by $35.9 \pm 1.7 \%(n=5, p<0.001$ vs. control group). Rosmarinic acid had no significant effect on the basal $\left[\mathrm{Ca}^{2+}\right]_{\mathrm{I}}(p=0.96)$. In addition, 4-AP (1 mM) evoked DiSC3(5) fluorescence increase and this effect was not affected by rosmarinic acid preincubation ( $n=5, p=0.9$ vs. control group, Table 1$)$.

Table 1. Effect of rosmarinic acid on cytosolic $\mathrm{Ca}^{2+}$ levels and synaptosomal membrane potential in rat cerebrocortical synaptosomes.

\begin{tabular}{ccccccc}
\hline & \multicolumn{3}{c}{ Cytosolic $\left[\mathbf{C a}^{2+}\right] \mathbf{( n M )}$} & \multicolumn{3}{c}{ DiSC $_{\mathbf{3}}$ (5) Fluorescence } \\
\cline { 2 - 7 } & Basal & 4-AP (1 $\mathbf{~ m M )}$ & $\boldsymbol{n}$ & Basal & 4-AP (1 $\mathbf{~ m M )}$ & $\boldsymbol{n}$ \\
\hline Control & $148.6 \pm 1.1$ & $196.7 \pm 3.1$ & 5 & $0.6 \pm 0.3$ & $24.7 \pm 1.6$ & 5 \\
Rosmarinic acid & $147.9 \pm 2.1$ & $170.7 \pm 4.0 * * *$ & 5 & $0.5 \pm 0.8$ & $24.3 \pm 1.8$ & 5 \\
\hline Data are mean \pm SEM $\left(n=5\right.$ per group). ${ }^{* * *} p<0.001$ compared with the control group.
\end{tabular}

\subsection{Effect of Rosmarinic Acid on Glutamate Release in the Presence of VGCC Blockers or Intracellular $\mathrm{Ca}^{2+}$ Release Inhibitors}

Either VGCCs or intracellular $\mathrm{Ca}^{2+}$ stores are responsible for the release of glutamate evoked by depolarization [32,33]. As shown in Figure 2, 4-AP-evoked glutamate release was reduced by $\omega$-CgTX GVIA ( $p<0.001$ vs. control group) and $\omega$-AgTX IVA $(p<0.001$ vs. control group), which selectively block N- and P/Q-type $\mathrm{Ca}^{2+}$ channels, respectively [32]. With $\omega$-CgTX GVIA or $\omega$-Aga IVA present, 4-AP-evoked glutamate release was further inhibited by rosmarinic acid ( $n=5, p<0.001$ vs. $\omega$-CgTX GVIA- or $\omega$-Aga IVA-treated group). However, the inhibitory action of rosmarinic acid was abolished in the presence of $\omega$-CgTX GVIA and $\omega$-Aga IVA. The release measured in the presence of $\omega$-CgTX GVIA and $\omega$-Aga IVA and rosmarinic acid wassimilar to that obtained in the presence of $\omega$-CgTX GVIA and $\omega$-Aga IVA ( $n=5, p=0.98$ vs. $\omega$-CgTX GVIA and $\omega$-Aga IVA-treated group). In addition, 4-AP-evoked glutamate release was reduced by dantrolene, an inhibitor of intracellular $\mathrm{Ca}^{2+}$ release from endoplasmic reticulum ( $p<0.001$ vs. control group), and CGP37157, an inhibitor of mitochondrial $\mathrm{Na}^{+} / \mathrm{Ca}^{2+}$ exchange $(p<0.001$ vs. control group). With dantrolene or CGP37157 present, rosmarinic acid was able to reduce 4-AP-evoked glutamate release ( $n=5, p<0.001$ vs. the dantrolene- or CGP37157-treated group, Figure 3). Furthermore, rosmarinic acid preincubation efficiently decreased $15 \mathrm{mM}$ KCl-evoked glutamate release ( $n=5, p<0.001$ vs. control group, Figure 2, inset), a process that involves $\mathrm{Ca}^{2+}$ influx primarily through VGCC opening [34]. 


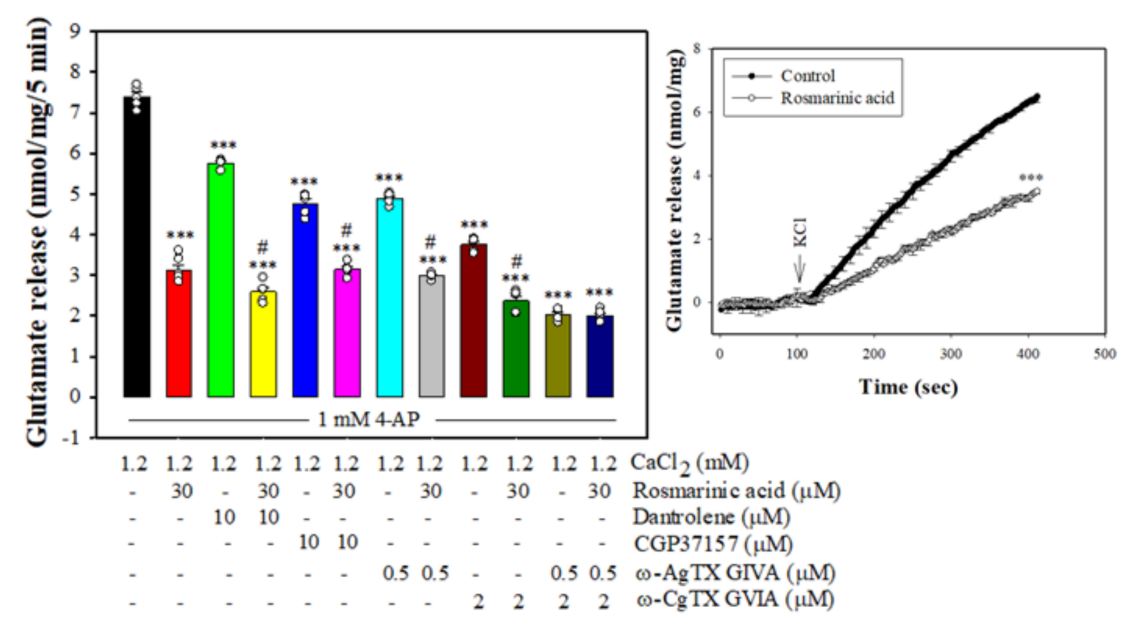

Figure 2. Effect of rosmarinic acid on 4-AP-evoked glutamate release in the presence of $\mathrm{N}$-type $\mathrm{Ca}^{2+}$ channel blocker $\omega$-CgTX GVIA, P/Q-type $\mathrm{Ca}^{2+}$ channel blocker $\omega$-AgTX IVA, ryanodine receptor inhibitor dantrolene, or mitochondrial $\mathrm{Na}^{+} / \mathrm{Ca}^{2+}$ exchanger inhibitor CGP37157. Inset, the inhibitory effect of rosmarinic acid on the release of glutamate evoked by $15 \mathrm{mM} \mathrm{KCl}$. Rosmarinic acid was added $10 \mathrm{~min}$ before the addition of 4-AP, and other drugs were added $10 \mathrm{~min}$ before this. Data are mean $\pm \operatorname{SEM}\left(n=5\right.$ per group). ${ }^{* * *} p<0.001$ compared with the control group. ${ }^{*} p<0.001$ compared with the dantrolene- or CGP37157-treated group.

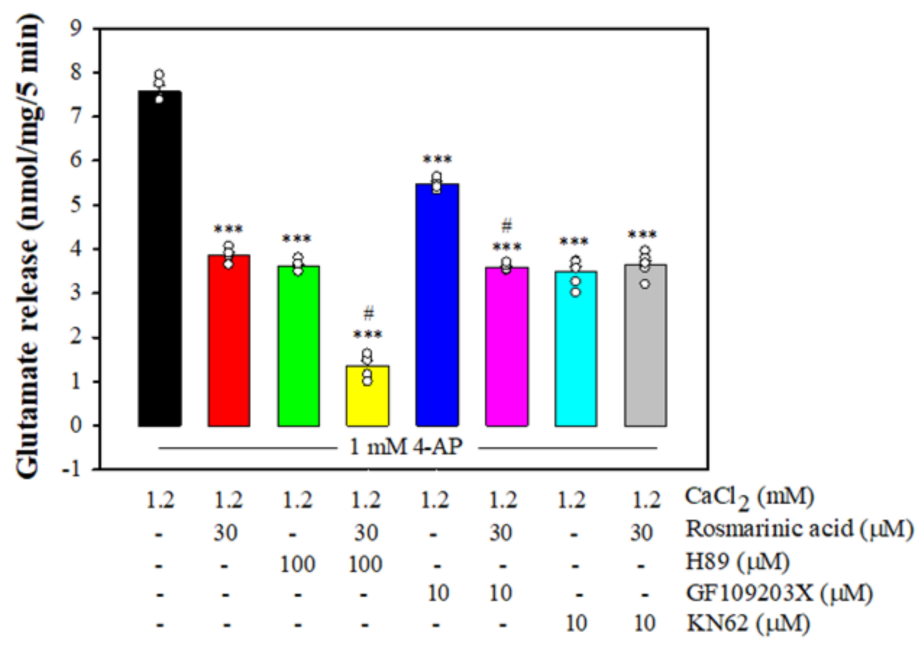

Figure 3. Effect of rosmarinic acid on 4-AP-evoked glutamate release in the presence of the PKA inhibitor H89, PKC inhibitor GF109203X or CaMKII inhibitor KN62. Rosmarinic acid was added 10 min before the addition of 4-AP, and other drugs were added $10 \mathrm{~min}$ before this. Data are mean \pm SEM ( $n=5$ per group). ${ }^{* *} p<0.001$ compared with the control group. ${ }^{*} p<0.001$ compared with the H89- or GF109203X-treated group.

\subsection{Effect of Rosmarinic Acid on Glutamate Release in the Presence of Protein Kinase Inhibitors}

Figure 3 shows that 4-AP-evoked glutamate release was reduced in the presence of H89, a protein kinase A (PKA) inhibitor, GF109203X, a PKC inhibitor, and KN63, a CaMKII inhibitor ( $p<0.001$ vs. control group). With H89 or GF109203X present, rosmarinic acid could still reduce the 4 -AP-evoked glutamate release $(p<0.001$ vs. H89- or GF109203Xtreated group). By contrast, rosmarinic acid did not produce any significant inhibition of glutamate release in the presence of KN62 ( $n=7, p=0.97$ vs. the KN62-treated group). 
3.5. Effect of Rosmarinic Acid on the Phosphorylation of CaMKII and Synapsin I (Serine 603, a Substrate Site of CaMKII) in Synaptosomes

Figure 4 shows a statistically significant increase in the phosphorylation of CaMKII and synapsin I was observed in the 4-AP group ( $p<0.001$ vs. control group). After pretreatment with rosmarinic acid, no significant increase in CaMKII and synapsin I phosphorylation was observed after exposure to $1 \mathrm{mM} 4-\mathrm{AP}$ compared with the control group $(n=5, p=0.9$, Figure 4).

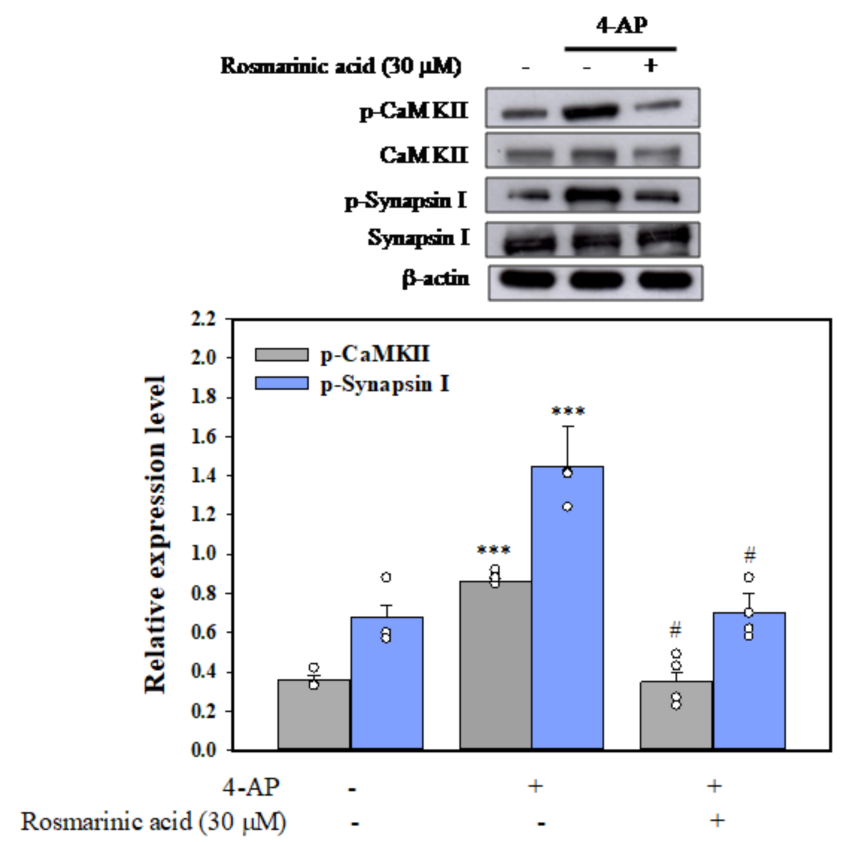

Figure 4. Effect of rosmarinic acid on CaMKII and synapsin I phosphorylation evoked by 4-AP. Rosmarinic acid or KN62 was added 10 min before the addition of 4-AP. Data are mean \pm SEM ( $n=5$ per group). ${ }^{* * *} p<0.001$ compared with the control group. ${ }^{\#} p<0.001$ compared with the 4-AP-treated group.

3.6. Effect of Rosmarinic Acid on Glutamate Release in the Presence of $G A B A_{A}$ Receptor Agonist and Antagonist

The central effects of rosmarinic acid have been shown to be associated with the modulation of $\gamma$-aminobutyric acid type $\mathrm{A}\left(\mathrm{GABA}_{\mathrm{A}}\right)$ receptors [35,36], which led us to ask the question of whether the effect of rosmarinic acid on glutamate release was mediated by $\mathrm{GABA}_{\mathrm{A}}$ receptors. We checked the presence of $\mathrm{GABA}_{\mathrm{A}}$ receptors in rat cerebrocortical synaptosomes by co-labeling with antibodies against the $\mathrm{GABA}_{\mathrm{A}}$ receptor $\alpha 1$ subunit, and the vesicular transporter of glutamate type 1 (VGLUT1), a glutamatergic terminal marker protein. As shown in Figure 5A, confocal microscopy showed that VGLUT1-positive glutamatergic particles (red) was immunopositive for the $\mathrm{GABA}_{\mathrm{A}}$ receptor $\alpha 1$ subunit (green). About $68.2 \pm 1.5 \%$ of the VGLUT1-positive particles were also positive for $\mathrm{GABA}_{\mathrm{A}}$ receptor $\alpha 1$ subunit (yellow). In addition, we examined the effect of isoguvacine, a $G_{A B A}$ receptor agonist, and SR95531, a GABA receptor antagonist, on the action of rosmarinic acid. Figure $5 \mathrm{~B}$ shows that the application of isoguvacine significantly reduced 4-APevoked glutamate release ( $n=5, p<0.001$ vs. control group). With isoguvacine present, rosmarinic acid had no significant effect on 4 -AP-evoked glutamate release ( $p=0.9$ vs. isoguvacine-treated group). A similar result was also obtained in the presence of SR95531. As shown in Figure 5B, rosmarinic acid failed to reduce 4-AP-evoked glutamate release in the presence of SR95531 ( $n=5, p=0.8$ vs. SR95531-treated group). However, SR95531 had no significant effect on control 4-AP-evoked glutamate release ( $p=0.2$ vs. control group). Furthermore, to predict the binding mode of rosmarinic acid, the molecular docking within 
the active site of $\mathrm{GABA}_{\mathrm{A}}$ receptor was based on the molecular structure (PDB ID 4COF) downloaded from RCSB protein data bank. The results indicated that rosmarinic acid formed six hydrogen-bonding interactions with the amino acid residues Asn149, Glu153, Arg192, Arg196, Ser209, and Ser211, respectively (Figure 6).

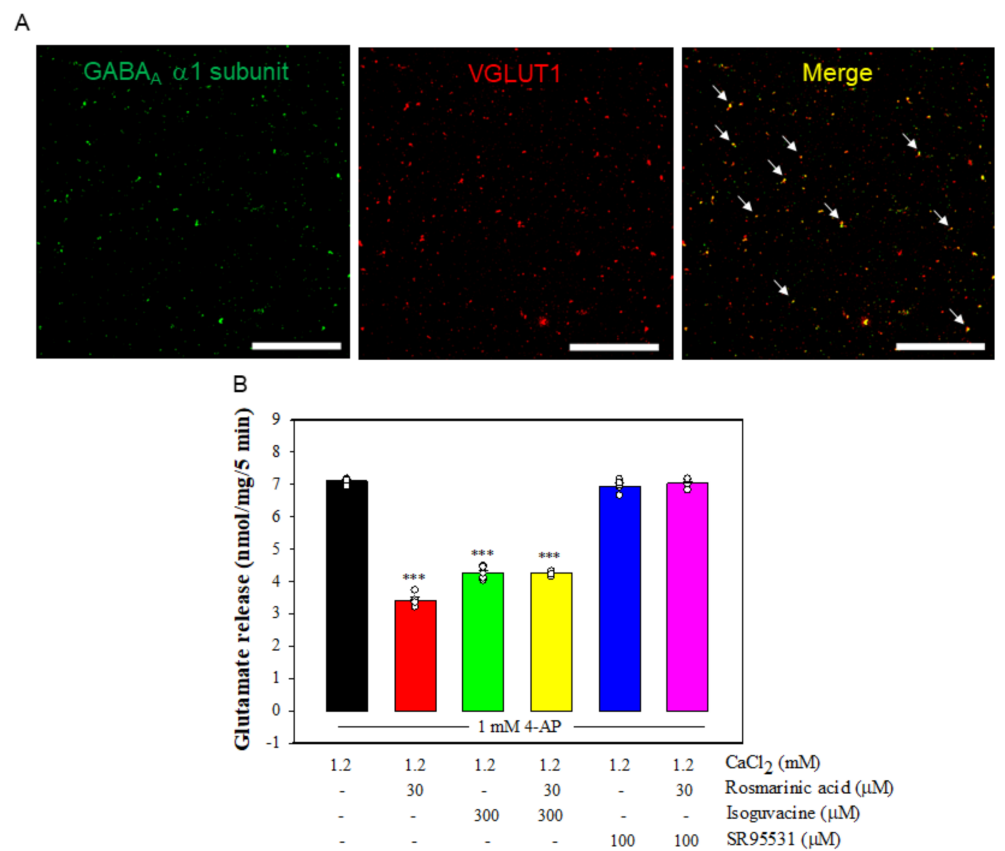

Figure 5. (A) $\mathrm{GABA}_{\mathrm{A}}$ receptor $\alpha 1$ subunits are present in VGLUT1-positive synaptosomal particles isolated from the rat cerebral cortex. Confocal microscopy unveiled a significant colocalization of VGLUT1 (red) and $\mathrm{GABA}_{\mathrm{A}}$ receptor $\alpha 1$ subunit (green) immunopositivities (yellow, merge, arrowhead). Scale bar: $100 \mu \mathrm{m}$. (B) Effect of rosmarinic acid on 4-AP-evoked glutamate release in the presence of isoguvacine and SR95531, GABA $\mathrm{A}$ receptor agonist and antagonist, respectively. Isoguvacine or SR95531 was added $10 \mathrm{~min}$ before the addition of 4 -AP. Data are mean \pm SEM $(n=5$ per group). ${ }^{* * *} p<0.001$ compared with the control group.

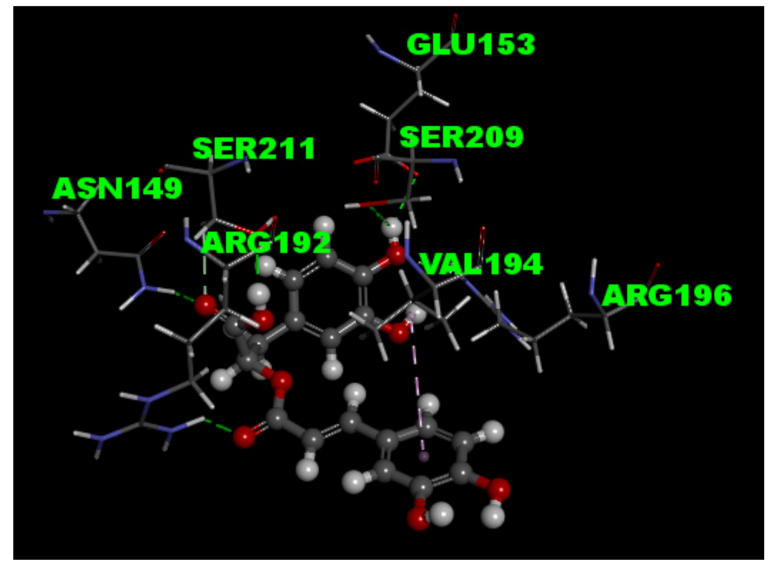

Figure 6. Prediction of the interaction of rosmarinic acid to $\mathrm{GABA}_{\mathrm{A}}$ receptor protein using molecular docking. Molecular docking modeling of rosmarinic acid with the active site of molecular structure of $\mathrm{GABA}_{\mathrm{A}}$ receptor protein (PDB ID 4COF) was performed using the Discovery Studio 4.1 software (BIOVIA software Inc., San Diego, CA, USA). Protein-ligand hydrogen-bonding interactions are displayed as green lines. 


\section{Discussion}

This is the first study of the effects of rosmarinic acid on central glutamatergic transmission. This work was centered on the modulation by rosmarinic acid of glutamate release from rat cerebrocortical synaptosomes. Rosmarinic acid, through $\mathrm{GABA}_{\mathrm{A}}$ receptor activation and CaMKII suppression, reduced 4-AP-evoked glutamate release.

Neuronal glutamate release is induced by 4-AP through two mechanisms: $\mathrm{Ca}^{2+}$ dependent vesicular release and $\mathrm{Ca}^{2+}$-independent release through the reversal of the plasma membrane glutamate uptake carrier [31,37]. In the current study, glutamate release inhibition by rosmarinic acid was prevented when external $\mathrm{Ca}^{2+}$ was removed, indicating the dependence of this inhibition on extracellular $\mathrm{Ca}^{2+}$. In addition, the blockage of vesicular release by bafilomycin $\mathrm{A} 1$, but not the blockage of glutamate transporters working in the reverse mode with DL-TBOA, abolished the rosmarinic acid-induced inhibition of glutamate release evoked by 4-AP. Our results indicate that the rosmarinic acid-mediated inhibition of glutamate release is mainly ascribable to a reduction in $\mathrm{Ca}^{2+}$-dependent exocytosis.

The modulation of 4-AP-evoked $\mathrm{Ca}^{2+}$-dependent glutamate release can occur at several putative sites in nerve terminals, including the $\mathrm{Na}^{+}, \mathrm{K}^{+}$, and $\mathrm{Ca}^{2+}$ channels. Modulation can also be achieved in the process of the release process itself. For instance, the inhibition of $\mathrm{Na}^{+}$channels or the activation of $\mathrm{K}^{+}$channels results in nerve terminal hyperpolarization, which causes a subsequent reduction in the presynaptic voltage-dependent neuronal entry of $\mathrm{Ca}^{2+}$ and a consequent reduction in glutamate release [38]. The present findings suggest that rosmarinic acid does not reduce synaptosomal excitability, which would in turn reduce the influx of $\mathrm{Ca}^{2+}$ and thereby reduce glutamate release. This is because rosmarinic acid significantly inhibited 4-AP- and $\mathrm{KCl}$-induced glutamate release. Another reason is that glutamate release induced by $1 \mathrm{mM} 4-\mathrm{AP}$ involved both $\mathrm{Na}^{+}$and $\mathrm{Ca}^{2+}$ channels, whereas that induced by $15 \mathrm{mM}$ external $\mathrm{KCl}$ involved only $\mathrm{Ca}^{2+}$ channels [31]. In other words, $\mathrm{Na}^{+}$channels were not involved in the inhibition of glutamate release by rosmarinic acid. Furthermore, no substantial effect of rosmarinic acid on synaptosomal membrane potential was observed either in the resting condition or during depolarization with 4-AP, thus indicating no effect on $\mathrm{K}^{+}$conductance.

In addition, the inhibition of glutamate release by rosmarinic acid was associated with a reduction in 4-AP-evoked increase in $\left[\mathrm{Ca}^{2+}\right]_{\mathrm{i}}$. During the depolarization of synaptosomes in $\mathrm{Ca}^{2+}$-containing medium, the elevation of $\left[\mathrm{Ca}^{2+}\right]_{\mathrm{i}}$ is mediated by $\mathrm{Ca}^{2+}$ influx through VGCCs and $\mathrm{Ca}^{2+}$ release from internal stores [32,33,39]. The rosmarinic acid-induced inhibition of 4-AP-evoked glutamate release from depolarized synaptosomes was completely abolished when $\mathrm{N}$ - and P/Q-type $\mathrm{Ca}^{2+}$ channels were blocked. However, neither dantrolene, an inhibitor of the release of intracellular $\mathrm{Ca}^{2+}$ from the endoplasmic reticulum, nor CGP37157, a mitochondrial $\mathrm{Na}^{+} / \mathrm{Ca}^{2+}$ exchange blocker, affected the inhibitory effect of rosmarinic acid on 4-AP-evoked glutamate release. These results suggest that rosmarinic acid can inhibit glutamate release by reducing the activity of VGCCs. However, how rosmarinic acid affects VGCCs remains to be elucidated.

In synaptic terminals, CaMKII, a serine/threonine kinase activated by $\mathrm{Ca}^{2+}$ and calmodulin regulates neurotransmitter release [40]. CaMKII has been reported to increase glutamate release by phosphorylating numerous synaptic proteins, including synapsin I [41-43]. The phosphorylation of synapsin I causes synaptic vesicles to dissociate from the cytoskeleton, thereby increasing the proportion of nerve terminal vesicles that are available for release [44-46]. In our study, the inhibitory effect of rosmarinic acid on glutamate release was abolished by the CaMKII inhibitor KN62. Moreover, rosmarinic acid inhibited the 4-AP-evoked phosphorylation of CaMKII and synapsin I. These results suggest that the suppression of CaMKII activity and the inhibition of synapsin I phosphorylation is involved in the rosmarinic acid-mediated inhibition of glutamate release. In addition to synapsin I, however, several other presynaptic proteins, including synaptophysin, syntaxin, and SNAP 25, have been demonstrated to be phosphorylated by CaMKII $[47,48]$. The possibility that these proteins are involved in phosphorylation inhibition with regard to the inhibition of rosmarinic acid release cannot be excluded. 
Rosmarinic acid is known to modulate the function of $\mathrm{GABA}_{\mathrm{A}}$ receptors [35,36]. Therefore, the question arises of whether the rosmarinic acid effect observed in our study involves an action on $\mathrm{GABA}_{\mathrm{A}}$ receptors. $\mathrm{GABA}_{\mathrm{A}}$ receptors, a large and diverse family of $\mathrm{Cl}^{-}$-permeable ion channels, mediate inhibitory neurotransmission in the CNS [49]. $\mathrm{GABA}_{\mathrm{A}}$ receptors are assembled from seven class of homologous subunits, $\alpha, \beta, \gamma, \delta$, $\varepsilon, \pi$, and $\theta$, into heteropentamers. The majority of $\mathrm{GABA}_{\mathrm{A}}$ receptors are composed of two $\alpha 1$, two $\beta 2$, and one $\gamma 2$ subunit ( $\alpha 1 \beta 2 \gamma 2$ receptors), which are primarily located synaptically and are involved in the hypnotic/sedative effects $[50,51]$. In the present study, immunocytochemical analysis of rat synaptosomes demonstrated that the $\mathrm{GABA}_{\mathrm{A}}$ receptor $\alpha 1$ subunitswere present on glutamatergic terminals, which is consistent with previous studies [52,53]. In addition, isoguvacine and SR95531, GABA $\mathrm{A}_{\mathrm{A}}$ receptor agonist and antagonist, respectively, blocked the inhibitory effect of rosmarinic acid on 4-APevoked glutamate release. Furthermore, our docking data revealed that rosmarinic acid can form hydrogen bond with the amino acid residues (Asn149, Glu153, Arg192, Arg196, Ser209, and Ser211) of GABA receptor. Since the amino acid residues Ser204, Tyr205, Arg207, and Ser209 in the loop C region of $\mathrm{GABA}_{\mathrm{A}}$ protein are the key residues face into GABA binding, and the loop F region (Asp192-Arg197) could interact with neighboring residues by hydrogen bonding and hydrophobic interaction, which change conformation during receptor activation $[54,55]$. Rosmarinic acid may be able to modulate the $\mathrm{GABA}_{\mathrm{A}}$ receptor activation through the interaction betweenArg192, Arg196, and Ser209. At the glutamatergic terminals, the activation of $\mathrm{GABA}_{\mathrm{A}}$ receptors cause the hyperpolarization through increasing $\mathrm{Cl}^{-}$influx, which would reduce action potentials. This reduction would decrease the presynaptic $\mathrm{Ca}^{2+}$ influx, which in turn would affect glutamate release [56]. In the present study, we did not examine the effect of rosmarinic acid on intracellular $\mathrm{Cl}^{-}$influx in cerebrocortical synaptosomes. However, rosmarinic acid has been shown to increase intracellular $\mathrm{Cl}^{-}$influx in primary cultured hypothalamic cells [35]. Based on these considerations, we infer that $\mathrm{GABA}_{\mathrm{A}}$ receptor activation of glutamatergic terminals by rosmarinic acid results in hyperpolarization, which reduces $\mathrm{Ca}^{2+}$ influx and the amount of glutamate released. In fact, enhancement of $\mathrm{GABA}_{\mathrm{A}}$ receptor activity has been championed by many studies as the potential target site for natural products $[57,58]$.

\section{Conclusions}

In conclusion, our results demonstrate for the first time that rosmarinic acid, through $\mathrm{GABA}_{\mathrm{A}}$ receptor activation to affect a reduction of $\mathrm{Ca}^{2+}$ influx and CaMKII/synapsin I pathway, inhibits glutamate release from rat cerebrocortical nerve terminals (Figure 7). As for glutamate, the neuroprotective properties of reduced glutamatergic neurotransmission are long-established [6-8]; therefore, the inhibition of glutamate release by rosmarinic acid may constitute an explanatory mechanism of its neuroprotective effects [21,22]. Although the relevance of our findings to clinical situations remains to be determined, they suggest that rosmarinic acid is a promising anti-excitotoxic drug for the treatment of neurological disorders involving glutamate excitotoxicity. 


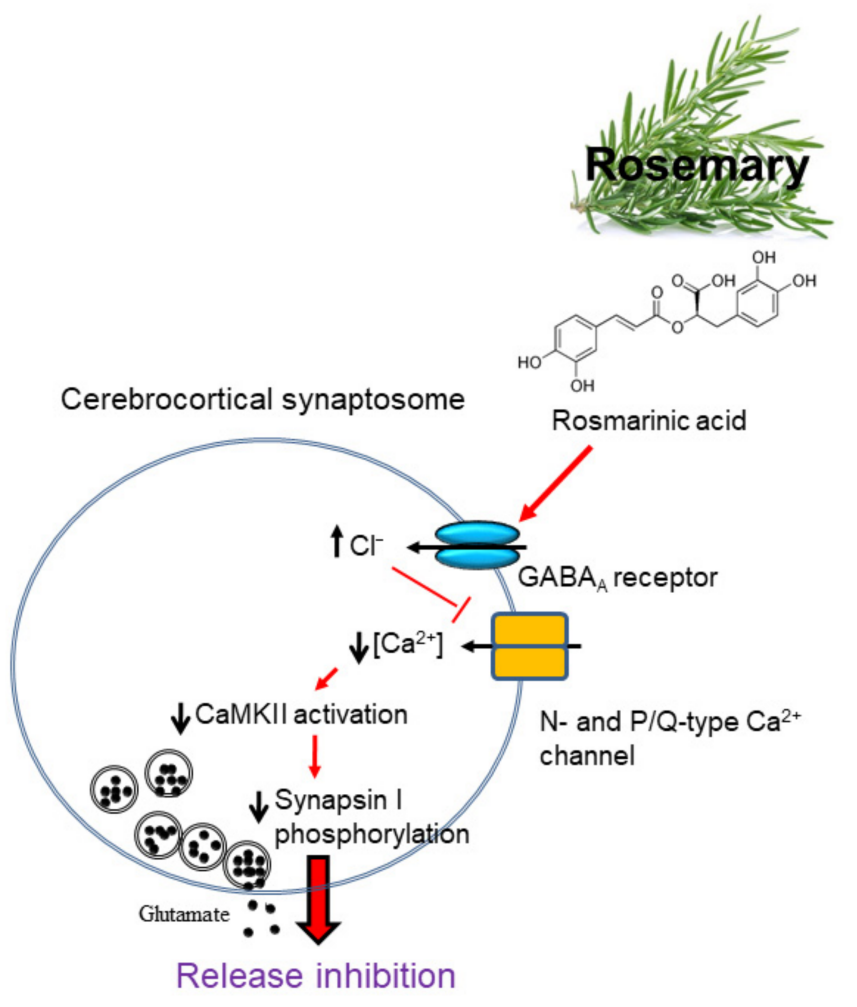

Figure 7. A proposed mechanism underlying the inhibition of glutamate release by rosmarinic acid in rat cerebrocortical synaptosomes.

Author Contributions: Conceptualization, C.-C.W. and S.-J.W.; formal analysis, P.-W.H., J.-R.K. and S.-J.W.; investigation, C.-C.W., P.-W.H., J.-R.K. and S.-J.W.; writing-original draft preparation, S.-J.W.; writing-review and editing, C.-C.W., P.-W.H. and S.-J.W.; supervision, S.-J.W. All authors have read and agreed to the published version of the manuscript.

Funding: This research was supported by the Ministry of Science and Technology (MOST 110-2320B-030-009) and the Chi-Mei Medical Center (107-CM-FJU-03), Taiwan.

Institutional Review Board Statement: All animal handing and experimental procedures were performed in accordance with the guidelines of the Care and Use of Laboratory Animals (NAC 2011) and were approved by the Fu Jen Institutional Animal Care and Utilization Committee (IACUC No. A10812).

Informed Consent Statement: Not applicable.

Data Availability Statement: The data presented in this study are available on request from the corresponding author.

Conflicts of Interest: The authors declare no conflict of interest.

\section{References}

1. Peng, S.; Zhang, Y.; Zhang, J.; Wang, H.; Ren, B. Glutamate receptors and signal transduction in learning and memory. Mol. Biol. Rep. 2011, 38, 453-460. [CrossRef]

2. Choi, D.W. Glutamate neurotoxicity and diseases of the nervous system. Neuron 1998, 1, 623-634. [CrossRef]

3. Bano, D.; Ankarcrona, M. Beyond the critical point: An overview of excitotoxicity, calcium overload and the downstream consequences. Neurosci. Lett. 2018, 663, 79-85. [CrossRef] [PubMed]

4. Lau, A.; Tymianski, M. Glutamate receptors, neurotoxicity and neurodegeneration. Pflügers Arch. Eur. J. Physiol. 2010, 460, 525-542. [CrossRef] [PubMed]

5. Lewerenz, J.; Maher, P. Chronic glutamate toxicity in neurodegenerative diseases-what is the evidence? Front. Neurosci. 2015, 9 , 469. [CrossRef]

6. Mdzinarishvili, A.; Sumbria, R.; Lang, D.; Klein, J. Ginkgo extract EGb761 confers neuroprotection by reduction of glutamate release in ischemic brain. J. Pharm. Pharm. Sci. 2012, 15, 94-102. [CrossRef] [PubMed] 
7. Wong, S.B.; Cheng, S.J.; Hung, W.C.; Lee, W.T.; Min, M.Y. Rosiglitazone suppresses in vitro seizures in hippocampal slice by inhibiting presynaptic glutamate release in a model of temporal lobe epilepsy. PLoS ONE 2015, 10, e0144806. [CrossRef] [PubMed]

8. Lazarevic, V.; Yang, Y.; Ivanova, D.; Fejtova, A.; Svenningsson, P. Riluzole attenuates the efficacy of glutamatergic transmission by interfering with the size of the readily releasable neurotransmitter pool. Neuropharmacology 2018, 143, 38-48. [CrossRef]

9. Rehman, M.U.; Wali, A.F.; Ahmad, A.; Shakeel, S.; Rasool, S.; Ali, R.; Rashid, S.M.; Madkhali, H.; Ganaie, M.A.; Khan, R. Neuroprotective strategies for neurological disorders by natural products: An update. Curr. Neuropharmacol. 2019, 17, $247-267$. [CrossRef] [PubMed]

10. Tóth, F.; Cseh, E.K.; Vécsei, L. Natural molecules and neuroprotection: Kynurenic acid, pantethine and $\alpha$-lipoic acid. Int. J. Mol. Sci. 2021, 22, 403. [CrossRef]

11. Al-Sereiti, M.R.; Abu-Amer, K.M.; Sen, P. Pharmacology of rosemary (Rosmarinus officinalis Linn) and its therapeutic potentials. Indian J. Exp. Biol. 1999, 37, 124-130. [PubMed]

12. Rahbardar, M.G.; Hosseinzadeh, H. Therapeutic effects of rosemary (Rosmarinus officinalis L.) and its active constituents on nervous system disorders. Iran J. Basic Med. Sci. 2020, 23, 1100-1112.

13. Aruoma, O.; Spencer, J.; Rossi, R.; Aeschbach, R.; Khan, A.; Mahmood, N.; Halliwell, B. An evaluation of the antioxidant and antiviral action of extracts of rosemary and provencal herbs. Food Chem. Toxicol. 1996, 34, 449-456. [CrossRef]

14. Bakirel, T.; Bakirel, U.; Keles, O.U.; Ulgen, S.G.; Yardibi, H. In Vivo assessment of antidiabetic and antioxidant activities of rosemary (Rosmarinus officinalis) in alloxan-diabetic rabbits. J. Ethnopharmacol. 2008, 116, 64-73. [CrossRef] [PubMed]

15. Rahbardar, M.G.; Amin, B.; Mehri, S.; Mirnajafi-Zadeh, S.J.; Hosseinzadeh, H. Anti-inflammatory effects of ethanolic extract of Rosmarinus officinalis L. and rosmarinic acid in a rat model of neuropathic pain. Biomed. Pharmacother. 2017, 86, 441-449. [CrossRef]

16. Moore, J.; Yousef, M.; Tsiani, E. Anticancer effects of rosemary (Rosmarinus officinalis L.) extract and rosemary Extract polyphenols. Nutrients 2016, 8, 731. [CrossRef] [PubMed]

17. González-Trujano, M.; Peña, E.; Martínez, A.; Moreno, J.; Guevara-Fefer, P.; Deciga-Campos, M.; López-Muñoz, F. Evaluation of the antinociceptive effect of Rosmarinus officinalis L. using three different experimental models in rodents. J. Ethnopharmacol. 2007, 111, 476-482. [CrossRef]

18. Machado, D.G.; Bettio, L.E.; Cunha, M.P.; Capra, J.C.; Dalmarco, J.B.; Pizzolatti, M.G.; Rodrigues, A.L.S. Antidepressant-like effect of the extract of Rosmarinus officinalis in mice: Involvement of the monoaminergic system. Prog. Neuro-Psychopharmacol. 2009, 33, 642-650. [CrossRef]

19. Naderali, E.; Nikbakht, F.; Ofogh, S.N.; Rasoolijazi, H. The role of rosemary extract in degeneration of hippocampal neurons induced by kainic acid in the rat: A behavioral and histochemical approach. J. Integr. Neurosci. 2018, 17, 19-25. [CrossRef]

20. Hosseinzadeh, H.; Karimi, G.; Noubakht, M. Effects of Rosmarinus officinalis L. aerial parts essential oil on intact memory and scopolamine-induced learning deficits in rats performing the Morris water maze task. J. Med. Plants 2004, 3, 51-57.

21. Fonteles, A.A.; de Souza, C.M.; de Sousa Neves, J.C.; Menezes, A.P.F.; Santos do Carmo, M.R.; Fernandes, F.D.P.; de Araújo, P.R.; de Andrade, G.M. Rosmarinic acid prevents against memory deficits in ischemic mice. Behav. Brain Res. 2016, 297, 91-103. [CrossRef]

22. Shimojo, Y.; Kosaka, K.; Noda, Y.; Shimizu, T.; Shirasawa, T. Effect of rosmarinic acid in motor dysfunction and life span in a mouse model of familial amyotrophic lateral sclerosis. J. Neurosci. Res. 2010, 88, 896-904. [CrossRef]

23. Rong, H.; Liang, Y.; Niu, Y. Rosmarinic acid attenuates $\beta$-amyloid-induced oxidative stress via Akt/GSK-3 $\beta /$ Fyn-mediated Nrf2 activation in PC12 cells. Free Radic. Biol. Med. 2018, 120, 114-123. [CrossRef]

24. Lee, H.J.; Cho, H.S.; Park, E.; Kim, S.; Lee, S.Y.; Kim, C.S.; Kim, D.K.; Kim, S.J.; Chun, H.S. Rosmarinic acid protects human dopaminergic neuronal cells against hydrogen peroxide-induced apoptosis. Toxicology 2008, 250, 109-115. [CrossRef]

25. Taram, F.; Ignowski, E.; Duval, N.; Linseman, D.A. Neuroprotection comparison of rosmarinic acid and carnosic acid in primary cultures of cerebellar granule neurons. Molecules 2018, 23, 2956. [CrossRef]

26. Su, I.C.; Hung, C.F.; Lin, C.N.; Huang, S.K.; Wang, S.J. Cycloheterophyllin inhibits the release of glutamate from nerve terminals of the rat hippocampus. Chem. Res. Toxicol. 2019, 32, 1591-1598. [CrossRef]

27. Chiu, K.M.; Lin, T.Y.; Lee, M.Y.; Lu, C.W.; Wang, M.J.; Wang, S.J. Typhaneoside suppresses glutamate release through inhibition of voltage-dependent calcium entry in rat cerebrocortical nerve terminal. Chem. Res. Toxicol. 2021, 34, 1286-1295. [CrossRef]

28. Grynkiewicz, G.; Poenie, M.; Tsien, R.Y. A new generation of $\mathrm{Ca}^{2+}$ indicators with greatly improved fluorescence properties. J. Biol. Chem. 1985, 260, 3440-3450. [CrossRef]

29. Akerman, K.E.; Scott, I.G.; Heikkilä, J.E.; Heinonen, E. Ionic dependence of membrane potential and glutamate receptor-linked responses in synaptoneurosomes as measured with a cyanine dye, DiS-C2-(5). J. Neurochem. 1987, 48, 552-559. [CrossRef] [PubMed]

30. Lu, C.W.; Lin, T.Y.; Chiu, K.M.; Lee, M.Y.; Huang, J.H.; Wang, S.J. Silymarin inhibits glutamate release and prevents against kainic acid-induced excitotoxic injury in rats. Biomedicines 2020, 8, 486. [CrossRef] [PubMed]

31. Tibbs, G.R.; Barrie, A.P.; Van Mieghem, F.J.; McMahon, H.T.; Nicholls, D.G. Repetitive action potentials in isolated nerve terminals in the presence of 4-aminopyridine: Effects on cytosolic free $\mathrm{Ca}^{2+}$ and glutamate release. J. Neurochem. 1989, 53, 1693-1699. [CrossRef] [PubMed]

32. Vázquez, E.; Sánchez-Prieto, J. Presynaptic modulation of glutamate release targets different calcium channels in rat cerebrocortical nerve terminals. Eur. J. Neurosci. 1997, 9, 2009-2018. [CrossRef] [PubMed]

33. Berridge, M.J. Neuronal calcium signaling. Neuron 1998, 21, 13-26. [CrossRef]

34. Barrie, A.P.; Nicholls, D.G.; Sanchez-Prieto, J.; Sihra, T.S. An ion channel locus for the protein kinase C potentiation of transmitter glutamate release from guinea pig cerebrocortical synaptosomes. J. Neurochem. 1991, 57, 1398-1404. [CrossRef] 
35. Kwon, Y.O.; Hong, J.T.; Oh, K.W. Rosmarinic acid potentiates pentobarbital-induced sleep behaviors and non-rapid eye movement (NREM) sleep through the activation of GABAA-ergic systems. Biomol. Ther. (Seoul) 2017, 25, 105-111. [CrossRef]

36. Zhang, C.; Liu, C.; Wu, H.; Wang, J.; Sun, Y.; Liu, R.; Li, T.; Yu, X.; Geng, D.; Sun, Y.K. Global analysis the potential medicinal substances of Shuangxia Decoction and the process in vivo via mass spectrometry technology. Front. Pharmacol 2021, $12,654807$. [CrossRef] [PubMed]

37. Nicholls, D.G.; Sihra, T.S.; Sanchez-Prieto, J. Calcium-dependent and -independent release of glutamate from synaptosomes monitored by continuous fluorometry. J. Neurochem. 1987, 49, 50-57. [CrossRef]

38. Nicholls, D.G. Presynaptic modulation of glutamate release. Prog. Brain Res. 1998, 116, 15-22.

39. Millán, C.; Sánchez-Prieto, J. Differential coupling of N- and P/Q-type calcium channels to glutamate exocytosis in the rat cerebral cortex. Neurosci. Lett. 2002, 330, 29-32. [CrossRef]

40. Hudmon, A.; Schulman, H. Neuronal $\mathrm{Ca}^{2+} /$ calmodulin-dependent protein kinase II: The role of structure and autoregulation in cellular function. Annu. Rev. Biochem. 2002, 71, 473-510. [CrossRef]

41. Nichols, R.A.; Sihra, T.S.; Czernik, A.J.; Nairn, A.C.; Greengard, P. Calcium/calmodulin-dependent protein kinase II increases glutamate and noradrenaline release from synaptosomes. Nature 1990, 343, 647-651. [CrossRef]

42. Hinds, H.L.; Goussakov, I.; Nakazawa, K.; Tonegawa, S.; Bolshakov, V.Y. Essential function of alpha-calcium/calmodulindependent protein kinase II in neurotransmitter release at a glutamatergic central synapse. Proc. Natl. Acad. Sci. 2003, 100, 4275-4280. [CrossRef] [PubMed]

43. León, D.; Sánchez-Nogueiro, J.; Marín-García, P.; Miras-Portugal, M.A. Glutamate release and synapsin-I phosphorylation induced by P2X7 receptors activation in cerebellar granule neurons. Neurochem. Int. 2008, 52, 1148-1159. [CrossRef]

44. Llinás, R.; Gruner, J.A.; Sugimori, M.; McGuinness, T.L.; Greengard, P. Regulation by synapsin I and Ca ${ }^{2+}$-calmodulin-dependent protein kinase II of the transmitter release in squid giant synapse. J. Physiol. 1991, 436, 257-282. [CrossRef] [PubMed]

45. Chi, P.; Greengard, P.; Ryan, T.A. Synaptic vesicle mobilization is regulated by distinct synapsin I phosphorylation pathways at different frequencies. Neuron 2003, 38, 69-78. [CrossRef]

46. Leenders, A.G.; Sheng, Z.H. Modulation of neurotransmitter release by the second messenger-activated protein kinases: Implications for presynaptic plasticity. Pharmacol. Ther. 2005, 105, 69-84. [CrossRef]

47. Ohyama, A.; Hosaka, K.; Komiya, Y.; Akagawa, K.; Yamauchi, E.; Taniguchi, H.; Sasagawa, N.; Kumakura, K.; Mochida, S.; Yamauchi, T.; et al. Regulation of exocytosis through $\mathrm{Ca}^{2+} / \mathrm{ATP}-$ dependent binding of autophosphorylated $\mathrm{Ca}^{2+} / \mathrm{calmodulin}^{-}$ activated protein kinase II to syntaxin 1A. J. Neurosci. 2002, 22, 3342-3351. [CrossRef]

48. Wang, Z.W. Regulation of synaptic transmission by presynaptic CaMKII and BK channels. Mol. Neurobiol. 2008, 38, 153-166. [CrossRef]

49. Sieghart, W. Structure, pharmacology, and function of GABAA receptor subtypes. Adv. Pharmacol. 2006, 54, 231-263.

50. Olsen, R.W.; Sieghart, W. GABAA receptors: Subtypes provide diversity of function and pharmacology. Neuropharmacol. 2009, 56, 141-148. [CrossRef]

51. Sieghart, W.; Sperk, G. Subunit composition, distribution and function of GABA receptor subtypes. Curr. Top. Med. Chem. 2002, 2, 795-816. [CrossRef]

52. Chang, C.Y.; Lin, T.Y.; Lu, C.W.; Wang, C.C.; Wang, Y.C.; Chou, S.S.; Wang, S.J. Apigenin, a natural flavonoid, inhibits glutamate release in the rat hippocampus. Eur. J. Pharmacol. 2015, 762, 72-81. [CrossRef]

53. Chang, Y.; Lin, T.Y.; Lu, C.W.; Huang, S.K.; Wange, Y.C.; Wang, S.J. Xanthohumol-induced presynaptic reduction of glutamate release in the rat hippocampus. Food Funct. 2016, 7, 212-226. [CrossRef]

54. David, A.; Wagner, D.A.; Czajkowski, C. Structure and dynamics of the GABA binding pocket: Anarrowing cleft that constricts during activation. J. Neurosci. 2001, 21, 67-74.

55. Padgett, C.L.; Lummis, S.C.R. The F-loop of the $\mathrm{GABA}_{\mathrm{A}}$ receptor gamma2 subunit contributes to benzodiazepine modulation. J. Biol. Chem. 2008, 283, 2702-2708. [CrossRef]

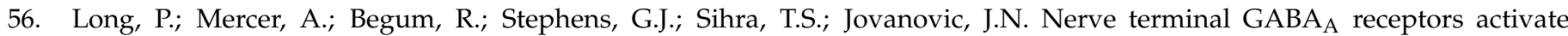
$\mathrm{Ca}^{2+} /$ calmodulin-dependent signaling to inhibit voltage-gated $\mathrm{Ca}^{2+}$ influx and glutamate release. J. Biol. Chem. 2009, 284, 8726-8737. [CrossRef]

57. Garlet, Q.I.; Rodrigues, P.; Barbosa, L.B.; Londero, A.L.; Mello, C.F.; Heinzmann, B.M. Nectandra grandiflora essential oil and its isolated sesquiterpenoids minimize anxiety-related behaviors in mice through GABAergic mechanisms. Toxicol. Appl. Pharmacol. 2019, 375, 64-80. [CrossRef] [PubMed]

58. Sonar, V.P.; Fois, B.; Distinto, S.; Maccioni, E.; Meleddu, R.; Cottiglia, F.; Acquas, E.; Kasture, S.; Floris, C.; Colombo, D.; et al. Ferulic acid esters and Withanolides: In search of Withania somnifera GABAA receptor modulators. J. Nat. Prod. 2019, 82, 1250-1257. [CrossRef] [PubMed] 